\title{
Diabetic mouse models
}

\author{
Yoshiaki Katsuda ${ }^{1}$, Takeshi Ohta ${ }^{1^{\star}}$, Masami Shinohara ${ }^{2}$, Tong Bin ${ }^{3}$, Takahisa Yamada ${ }^{3}$ \\ ${ }^{1}$ Japan Tobacco Inc., Central Pharmaceutical Research Institute, Takatsuki, Japan; ${ }^{*}$ Corresponding Author: takeshi.ota@jt.com \\ ${ }^{2}$ Planning and Development Section, CLEA Japan Inc., Tokyo, Japan \\ ${ }^{3}$ Laboratory of Animal Genetics, Graduate School of Science and Technology, Niigata University, Niigata, Japan
}

Received 11 September 2013; revised 16 October 2013; accepted 26 October 2013

Copyright (C) 2013 Yoshiaki Katsuda et al. This is an open access article distributed under the Creative Commons Attribution License, which permits unrestricted use, distribution, and reproduction in any medium, provided the original work is properly cited.

\begin{abstract}
The number of patients with lifestyle-related diseases, such as cardiovascular disease, diabetes mellitus, hypertension, atherosclerosis, and cancer, is increasing all over the world, and that of diabetics is increasing especially rapidly. Diabetic animal models have played a key role in elucidating the etiology of diabetes and developing anti-diabetic drugs. In this review, we overviewed characteristics of diabetic mouse models and pharmacological evaluation using the diabetic models.
\end{abstract}

Keywords: Diabetes; Diabetic Complication; Mouse Model; Obesity

\section{INTRODUCTION}

Diabetes has become a global health problem, and the incidence of diabetes is rapidly increasing in all regions of the world. The prevalence of diabetes across the world is forecast to increase from 171 million in 2000 to 366 million in 2030 [1].

Diabetes is classified into two categories: type 1 and type 2 . Type 1 diabetes is characterized by a loss of insulin secretion due to pancreatic $\beta$-cell degeneration, leading to autoimmune attack. Type 2 diabetes is a metabolic disorder that is caused by insufficient insulin secretion and/or insulin resistance in peripheral and liver tissues [2].

To help develop new diabetic therapies, it is important to reveal the complex mechanisms of diabetes mellitus. In particular, investigations using diabetic animal models are essential to clarify the pathogenesis and progression in human disease course [3]. We reviewed nonobese diabetic (NOD) mouse and nonobese C57BL/6 mutant (Akita) mouse as type 1 diabetic models, and $L_{e p}{ }^{o b}$ mutant (ob/ob) mouse, Lep ${ }^{d b}$ mutant $(\mathrm{db} / \mathrm{db})$ mouse, $\mathrm{KKA}^{\mathrm{y}}$ mouse, and Tsumura Suzuki obese diabetes (TSOD) mouse as type 2 diabetic models, with respect to characteristic features and pharmacological evaluations using the diabetic models.

\section{TYPE 1 DIABETIC MOUSE MODELS}

It is known that type 1 diabetes is caused by autoimmune destruction of $\beta$ cells of pancreas in genetically susceptible individuals. Understanding of the genetics and mechanisms of the disease has been facilitated by the use of nonobese diabetic (NOD) mouse. Another mouse model, nonobese C57BL/6 mutant (Akita) mouse, develops early age-onset diabetes, characterized by an autosomal dominant mode of inheritance.

\subsection{NOD Mouse}

\subsubsection{Background and Characteristics}

NOD mouse was established as an inbred strain of mouse with spontaneous development of autoimmune type 1 diabetes by Makino et al. in Shionogi laboratory [4]. The origin of the NOD traces back to a mouse with cataract among Jcl:ICR mice in 1966. Later, an inbred strain of mouse with cataracts and small eyes, the CTG mouse, was established by Ohtori et al. [5]. After selective breeding for hyperglycemia and euglycemia over about 10 generations, two sublines were transferred to Makino's group, and strict brother-sister mating was started. At the $20^{\text {th }}$ generation in selective breeding, a mouse with polyuria, polydipsia, and weight loss was found in the line with normal fasting blood glucose levels (approximately $100 \mathrm{mg} / \mathrm{dl}$ ). Inbreeding was continued with this mouse to establish an inbred strain with spontaneous development of diabetes, which culminated in a strain currently known as the NOD mouse.

In NOD mice, infiltration of monocular cells into pancreatic islets, insulitis, was observed at about 4 weeks of age [6]. The infiltrating monocular cells were mostly $\mathrm{T}$ cells (CD4+ and $\mathrm{CD} 8+$ ), and macrophages were also observed. $\beta$ cell destruction became aggressive after 15 weeks of age and overt diabetes developed. After the 
onset of diabetes, NOD mice showed decreased body weight and died within one to two months unless treated with insulin injection [4]. Sex differences in incidence of diabetes existed, and the cumulative incidence of diabetes in Shionogi laboratory was approximately $80 \%$ in females and less than $20 \%$ in males at 30 weeks of age [4]. Moreover, diet, room temperature, and pathogens have been suggested as factors influencing the incidence of diabetes [7-9], but the exact causes are still unknown.

\subsubsection{Pharmacological Evaluation}

It was reported that thiazolidinediones (TZDs) reduced diabetes incidence in NOD mice [10,11]. Rosiglitazone and troglitazone both significantly reduced the diabetic incidence in NOD mice as compared with litter-matched control mice. The effect is considered to have been induced by anti-inflammatory properties of TZDs. Combined treatment with lisofyline to inhibit autoimmunity and exendin- 4 to enhance $\beta$ cell proliferation showed therapeutic effects in NOD mice [12]. Since NOD mice develop autoimmune-mediated inflammation of pancreatic islets, anti-inflammatory drugs are reported to be useful for prevention or treatment of diabetes in the mice $[13,14]$.

\subsection{Akita Mouse}

\subsubsection{Background and Characteristics}

A nonobese C57BL/6 mutant mouse found in Akita colony, which spontaneously develops early age-onset diabetes, is characterized by an autosomal dominant mode of inheritance. In Akita mice, a diabetic locus named MODY4, was mapped to chromosome 7 in the region distal to D7Mit189 [15].

Akita mice develop diabetic symptoms, such as hyperglycemia, polydipsia, and polyuria, soon after weaning. The diabetic symptoms progress continuously in males, but the females exhibit mild symptoms. Survival rate in the male mice decreases gradually after about 25 weeks of age, and the rate at 52 weeks of age is about $20 \%$. Neither infiltration of lymphocyte nor any signs of inflammatory reactions were detectable in pa the ncreas, but selective decreases in densities of active $\beta$ cells occurred in Akita mice [15]. In Akita mice, furthermore, it was reported that the Ins 2 mutation resulted in a single amino acid substitution in the insulin 2 gene, which causes misfolding of insulin protein. For this mutation, Akita mice showed progressive loss of $\beta$ cell function, $\beta$ cell mass reduction, and overt hyperglycemia, as early as 4 weeks of age.

There are some reports of kidney injury in Akita mice. At 6 months of age, albumin excretion and glomerular filtration rate (GFR) were increased and pathological changes such as glomerular hypertrophy and increases in mesangial matrix were observed $[16,17]$. It was consid- ered that hyperglycemia in Akita mice induced oxidative stress and the kidney injury was caused possibly by the oxidation stress [18]. In examination of the diabetic peripheral neuropathy, Akita mice presented decreased motor nerve conduction velocity (MNCV), sensory nerve conduction velocity (SNCV), and slower reaction time to heat [19]. Moreover, there are some reports of retinal complications in diabetic Akita mouse model. Akita mice showed decreased retinal blood flow after several weeks of hyperglycemia [20], and the retinal ganglion cells were lost from the peripheral retina within 12 weeks of diabetes onset [21]. Furthermore, the mice showed increased retinal vascular permeability, increased acellular capillaries, and alterations in morphology of astrocyte and microglia from 12 to 36 weeks of hyperglycemia [22,23].

\subsubsection{Pharmacological Evaluation}

Recently, drug therapies for diabetic complications in Akita mice have been reported. Koshizaka et al. reported that telmisartan, an angiotensin II type 1 receptor blocker, prevented diabetic nephropathy through the inhibition of Notch pathway [24]. Furthermore, Chen et al. reported that fenofibrate, a peroxisome proliferator-activated receptor $\alpha(\operatorname{PPAR} \alpha)$ agonist, showed therapeutic effects on diabetic retinopathy in Akita mice [25]. Fenofibrate attenuated overexpression of intercellular adhesion molecule (ICAM)-1, monocyte chemoattractant protein (MCP)-1, and vascular endotherial growth factor (VEGF), and inhibited activation of hypoxia-inducible factor (HIF)-1 and nuclear factor (NF)- $\mathrm{KB}$ in retina of Akita mice.

\section{TYPE 2 DIABETIC MOUSE MODELS}

It is known that $90 \%-95 \%$ of diabetes is diagnosed as type 2 diabetes [2]. Type 2 diabetes is a heterogeneous disease with multiple etiologies. The incidence and progression of diabetes characterized by insulin resistance and/or impaired insulin secretion are caused by genetic and environmental factors. The etiology is considered to be multigenetic rather than monogenic. The development of diabetic animal models and pathophysiological analyses of the models are very important to aid in clarification of the pathogenesis and the patterns of progression in the human disease course. Diabetic mouse models, such as ob/ob mouse, db/db mouse, and $\mathrm{KKA}^{\mathrm{y}}$ mouse, are most commonly used in such studies.

\subsection{Ob/Ob Mouse}

\subsubsection{Background and Characteristics}

NOD $\mathrm{Lep}^{o b}$ mutation on chromosome 6 was discovered at the Jackson laboratory in a multiple recessive stock in 1949 [26], and the $\operatorname{Lep}^{o b}$ mutation was subsequently transferred to B6 inbred strain background [27]. Lep $^{o b}$ mutation on the B6 background (ob/ob) mice 
shows obesity, hyperinsulinemia, and relatively mild hyperglycemia.

Blood glucose levels in ob/ob mice increased as compared with those in lean mice from 7 to 11 weeks of age (Figure 1), but the levels decreased with aging and nor-

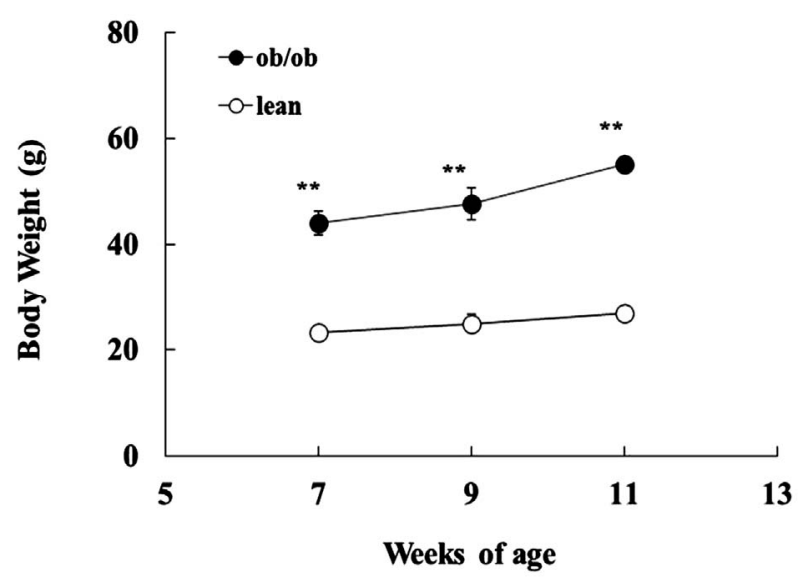

(a)

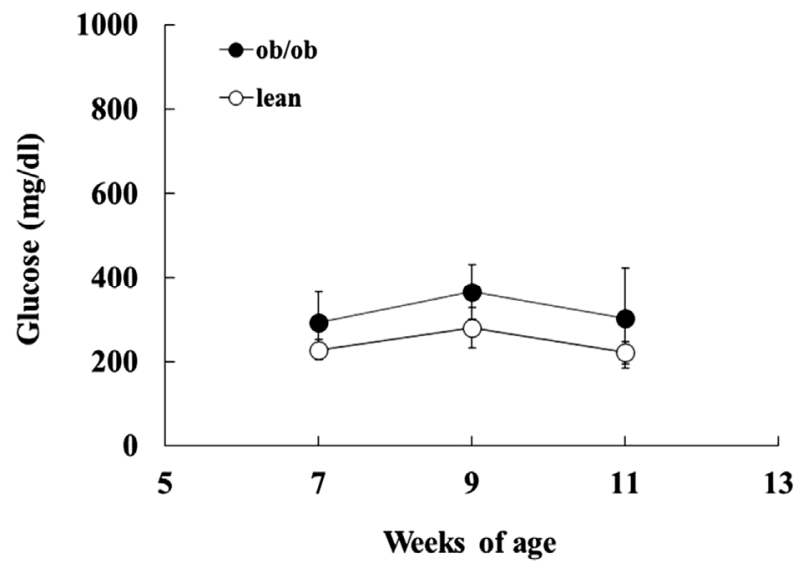

(b)

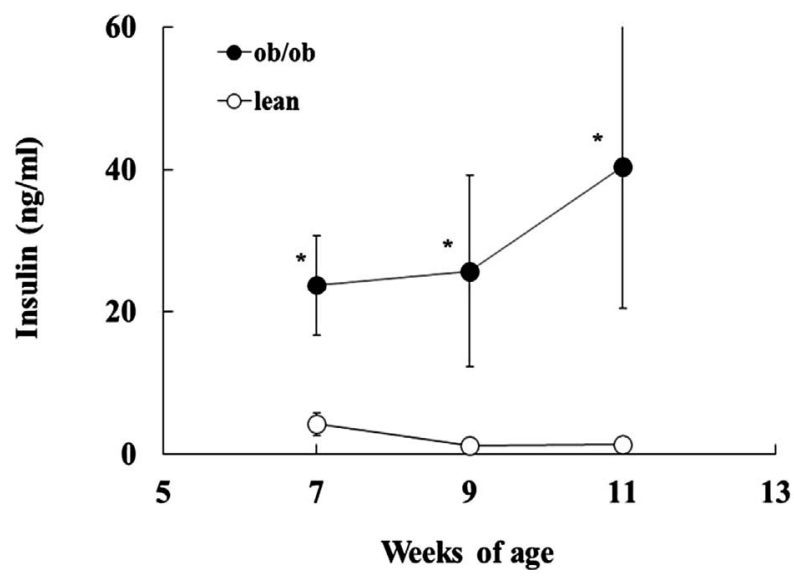

(c)

Figure 1. Changes in body weights (a); blood glucose (b) and insulin (c) levels in ob/ob and the lean mice. Data represent mean \pm standard deviation $(n=4)$. ${ }^{*} \mathrm{p}<0.05,{ }^{* *} \mathrm{p}<0.01$ : significantly different from lean mice. malized after at about 12 weeks of age. The remission from hyperglycemia was correlated with a sustained hypertrophy of pancreatic islets or hyperinsulinemia. The abnormal adipose tissue enlargement with hyperphagia was observed in ob/ob mice [28]. De novo lipogenesis was markedly enhanced in ob/ob mice as compared with lean mice, and the hepatic fatty acid synthesis was increased 6-fold per total liver and 2.2-fold per total small intestine [29]. The lipolytic defect in adipose tissue was observed, and one of the reasons was considered to be $\beta_{3}$-adrenergic receptor dysfunction in white adipose tissue [30].

\subsubsection{Pharmacological Evaluation}

There are some reports on anti-diabetic effects using ob/ob mice. Two-week treatment with vanadyl complex showed decreases in blood glucose, insulin, and triglyceride levels and ameliorated the impaired glucose tolerance [31]. The mechanism of the effects is considered to include attenuation of tumor necrosis factor (TNF)- $\alpha$ induced decrease in insulin receptor substrate (IRS)-1 phosphorylation. Other compounds, such as glycogen phosphorylase inhibitor, $\beta-3$ adrenoceptor agonist, and exendin-4, showed anti-diabetic effects in ob/ob mice [32-34]. We developed a protein tyrosine phosphatase (PTP)-1B inhibitor that shows an enhancement of insulin signaling, using ob/ob mice [35]. In ob/ob mice, PTP-1B inhibitor enhanced the insulin receptor-phosphorylation and showed the glucose-lowering effect (Figure 2).

\section{2. $\mathrm{db} / \mathrm{db}$ Mouse}

\subsubsection{Background and Characteristics}

Lepr $^{d b}$ mutation is a recessive mutation on chromosome 4 that occurred in $\mathrm{C} 57 \mathrm{BL} \mathrm{KS} / \mathrm{J}$ inbred strain in 1966 [36]. The Lepr $^{d b}$ mutation was subsequently transferred to the C57BL KS/J inbred strain by backcrossing.

$\mathrm{db} / \mathrm{db}$ mice resemble ob/ob mice in terms of a rapid development of obesity after weaning, but the diabetes syndrome is more severe. Blood glucose level at 7 weeks of age in $\mathrm{db} / \mathrm{db}$ mice is about $700 \mathrm{mg} / \mathrm{dl}$ (Figure 3), and the hyperglycemia is sustained over the life span. The blood insulin levels increase from 7 to 9 weeks of age (Figure 3), but the insulin levels decrease gradually with aging. The transient hyperglycemia and the progressive hyperglycemia are correlated with morphological levels with pancreatic $\beta$ cell necrosis and islet atrophy. Since the severe hyperglycemia is sustained in $\mathrm{db} / \mathrm{db}$ mice, diabetic complications such as nephropathy and neuropathy are observed. The $\mathrm{db} / \mathrm{db}$ mice had a decline in creatinine clearance after 20 weeks of age, and displayed substantial glomerular pathology, including mesangial expression and albuminuria [37,38]. There are some reports of neuropathy and retinopathy in $\mathrm{db} / \mathrm{db}$ mice $[39$, 40]. Impaired MNCV was observed during the early phase 


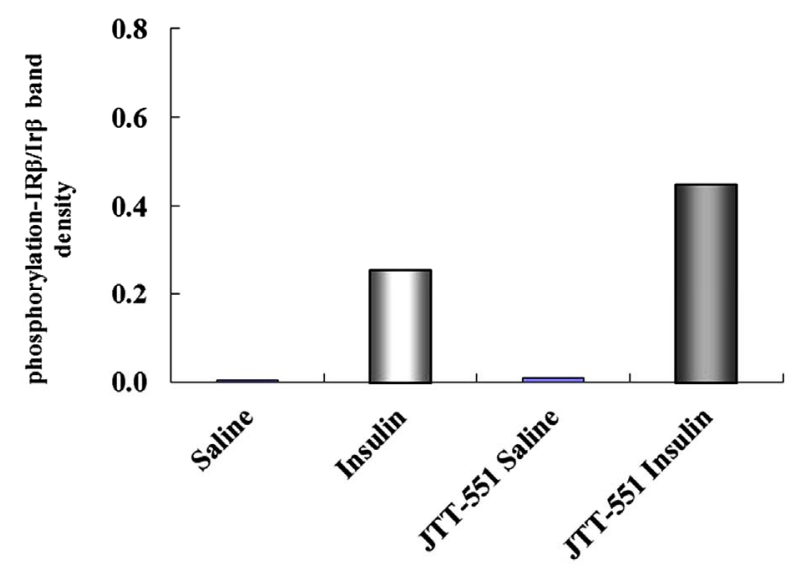

(a)

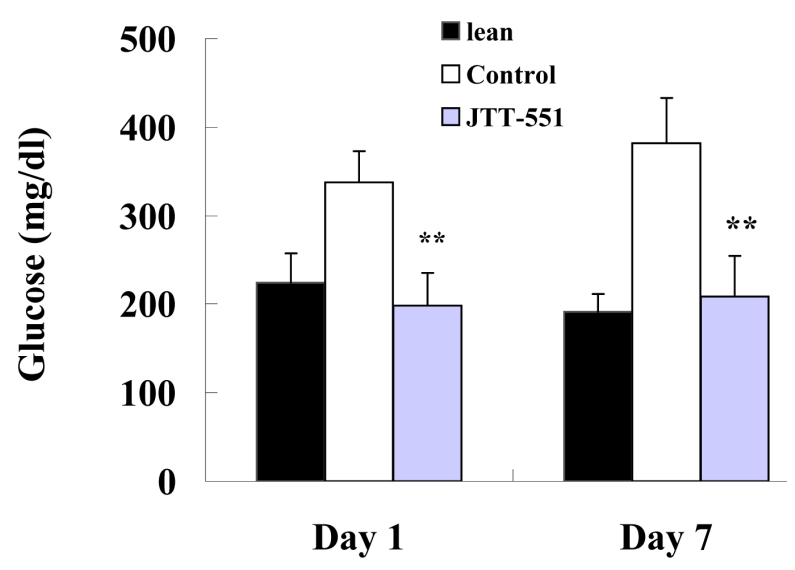

(b)

Figure 2. Effects on PTP-1B inhibitor (JTT-551) in ob/ob mice. (a) Enhancement effect of JTT-551 $(10 \mathrm{mg} / \mathrm{kg})$ on the insulin receptor (IR) phosphorylation in liver of ob/ob mice. The intensity of the IR phosphorylation was calculated as the ratio of the density of phosphorylation-IR $\beta$ to the density of IR $\beta$; (b) Effect of JTT-551 (10 mg/kg) on blood glucose in $\mathrm{ob} / \mathrm{ob}$ mice. JTT-551 was administered to the mice for 7 days. Blood samples were collected at $3 \mathrm{~h}$ after dosing. Data represent mean + standard deviation $(\mathrm{n}=5) .{ }^{* *} \mathrm{p}<0.01$ : significantly different from the control (ob/ob mice).

of the diabetic syndrome. In morphological study, $\mathrm{db} / \mathrm{db}$ mice showed loss or shrinkage of myelinated fibers in sural nerve and ventral root, and axonal atrophy [41,42]. In the retina, pathological changes such as loss of pericytes and acellular capillaries were observed [40].

\subsubsection{Pharmacological Evaluation}

There are many reports in which $\mathrm{db} / \mathrm{db}$ mice showed anti-diabetic potency. Recently, it was reported that novel compounds, such as GPR119 agonists and PTP-1B inhibitors, show anti-diabetic effects in $\mathrm{db} / \mathrm{db}$ mice $[43,44]$. A novel PTP-1B inhibitor that we developed also showed good glycemic control in $\mathrm{db} / \mathrm{db}$ mice (Figure 4) [35]. Furthermore, combination therapy with pioglitazone, a $\operatorname{PPAR} \gamma$ agonist, and alogliptin, a dipeptidyl peptidase

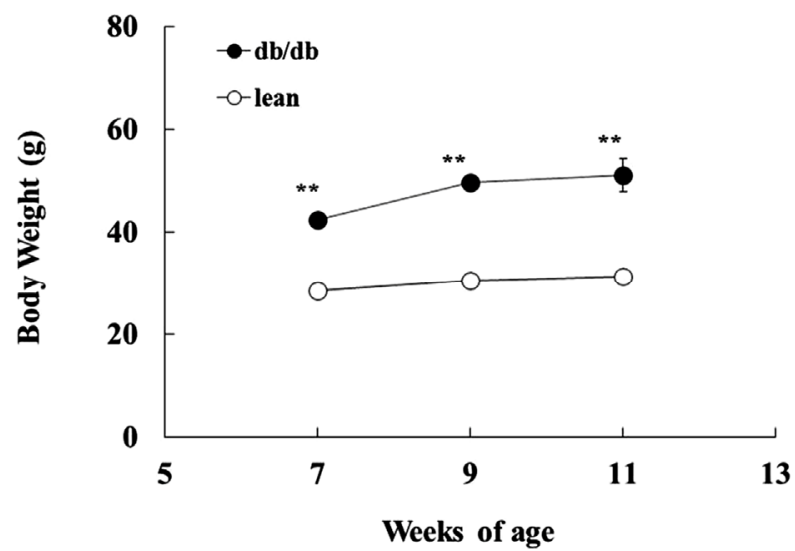

(a)

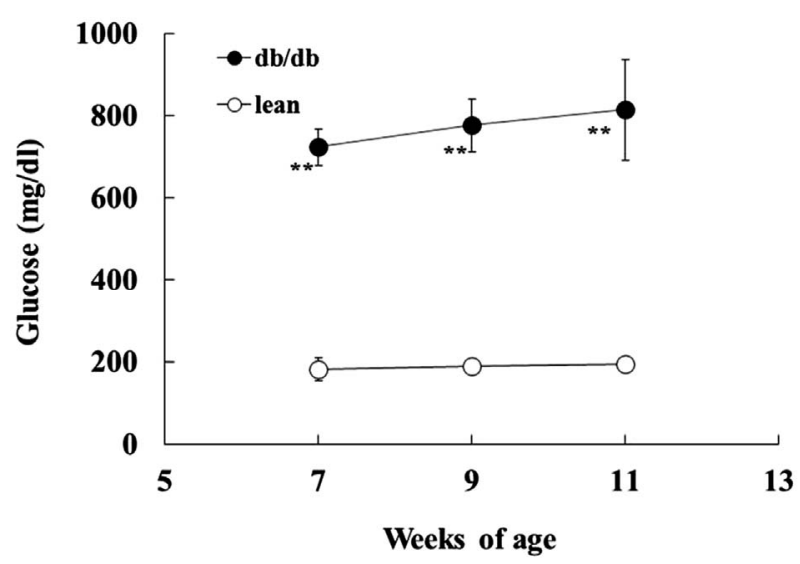

(b)

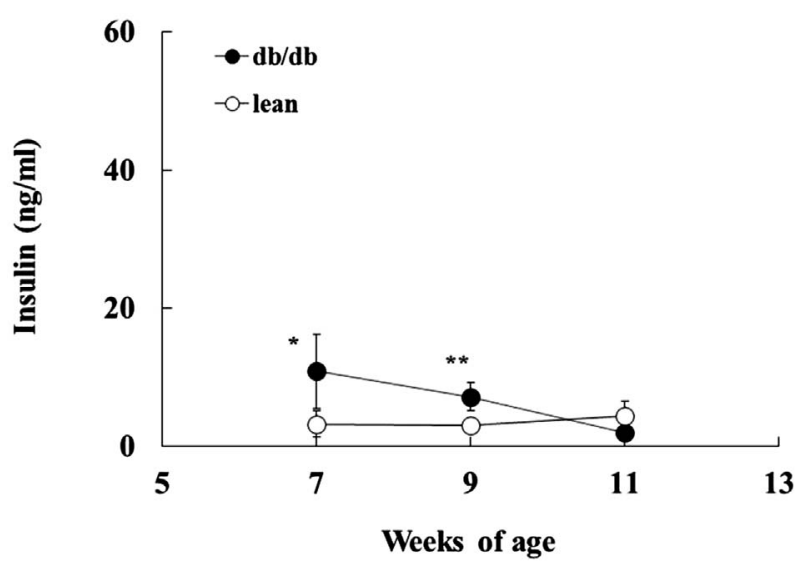

(c)

Figure 3. Changes in body weights (a); blood glucose (b) and insulin (c) levels in $\mathrm{db} / \mathrm{db}$ and the lean mice. Data represent mean \pm standard deviation $(\mathrm{n}=4)$. ${ }^{*} \mathrm{p}<0.05,{ }^{* *} \mathrm{p}<0.01$ : significantly different from lean mice.

(DPP)IV inhibitor, completely normalized $\beta$ cell functions in $\mathrm{db} / \mathrm{db}$ mice [45]. Recently, also, there have been many reports about pharmacological effects on diabetic complications in $\mathrm{db} / \mathrm{db}$ mice. It was reported that treatment with various compounds, such as fibroblast growth factor (FGF) 21, erythropoietin, C-C chemokine receptor 


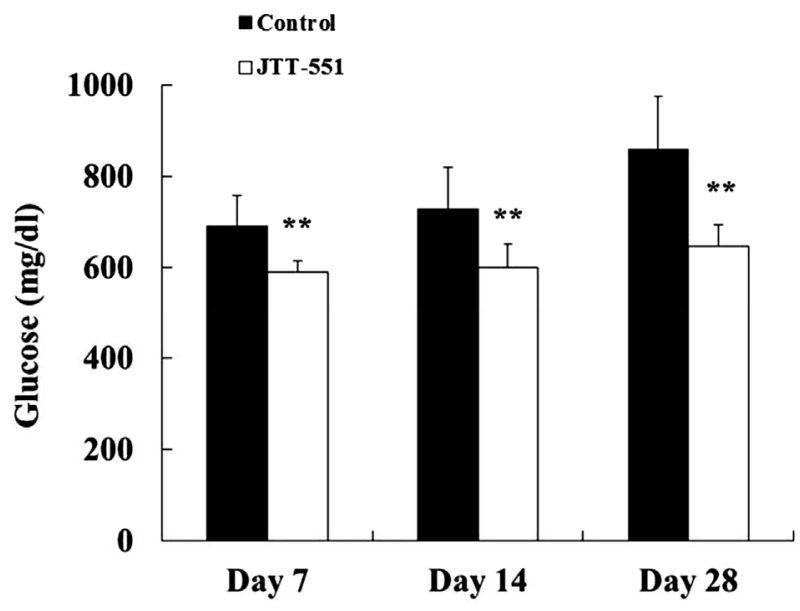

(a)

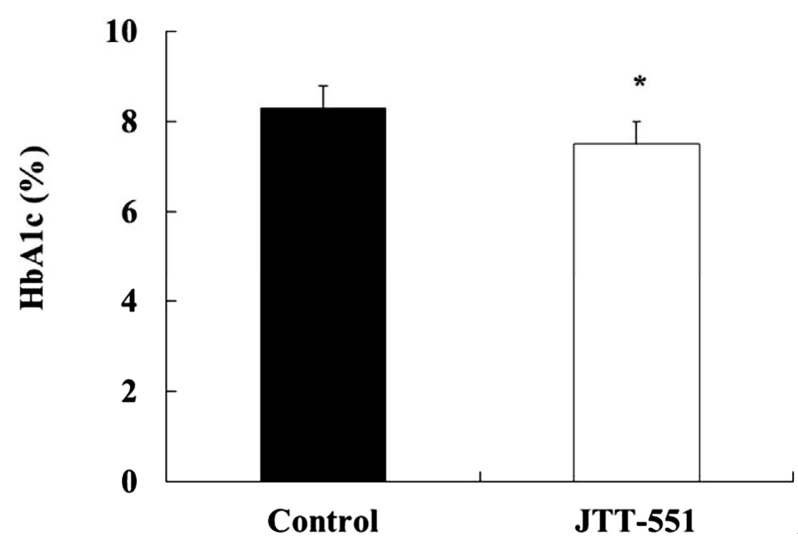

(b)

Figure 4. Effect of JTT-551 (30 mg/kg) on blood glucose (a) and $\mathrm{HbAlc}(\mathrm{b})$ levels in $\mathrm{db} / \mathrm{db}$ mice. JTT-551 was administered to the mice for 4 weeks. ${ }^{*} \mathrm{p}<0.05,{ }^{* *} \mathrm{p}<0.01$ : significantly different from the control.

type 2 (CCR2) inhibitor, and nuclear factor of activated T cells (NFAT) inhibitor, ameliorated diabetic nephropathy in $\mathrm{db} / \mathrm{db}$ mice [46-49]. Interestingly, in erythropoietin or NFAT inhibitor treatment, one of the therapeutic targets is a protection effect against podocyte injury $[47,48]$. Tofogliflozin, a novel sodium/glucose cotransporter (SGLT)2 inhibitor, or celastrol, an NF-kB inhibitor, also improved renal injury in $\mathrm{db} / \mathrm{db}$ mice [50,51].

\subsection{KKAy Mouse}

\subsubsection{Background and Characteristics}

Kondo et al. selected and established many mouse strains from Japanese native mice [52]. Among these inbred strains, Nakamura et al. found that the KK mouse is spontaneously diabetic [52,53]. Since diabetes and obesity in KK mice were relatively moderate, Nishimura et al. transferred the yellow obese gene $\left(\mathrm{A}^{\mathrm{y}}\right)$ into $\mathrm{KK}$ mice by crossing yellow obese mice with KK mice [54]. The $\mathrm{A}^{\mathrm{y}}$ allele was associated phenotypically with yellow fur, hyperphagia, and obesity $[55,56]$. This congenic strain of KK mice has been named $\mathrm{KK}^{\mathrm{y}}$ mouse.

In $\mathrm{KK}^{\mathrm{y}}$ mice, diabetic characteristics, such as obesity, hyperinsulinemia, and hyperglycemia, were observed from young ages ( $6-8$ weeks of age), but reverted apparently to normal after 40 weeks of age [57, 58]. Insulin resistance in $\mathrm{KK} \mathrm{A}^{\mathrm{y}}$ mouse is considered to be caused by various physiological changes, such as reduction in serum adiponectin levels, high activities of gluconeogenesis-enzymes in liver, and elevated production of TNF- $\alpha$ or other cytokines $[59,60]$. In pancreas of $\mathrm{KK} \mathrm{A}^{\mathrm{y}}$ mice, pathohistological changes, such as degranulation, glycogen deposition, and hypertrophy $\beta$ cells were observed at 5 - 10 weeks of age, suggesting that synthesis and release of insulin were increased with hyperinsulinemia [61]. In $\mathrm{KK}^{\mathrm{y}}$ mice, renal lesions, such as diffuse glomerulosclerosis, nodular changes, and peripheral glomerular basement membrane (GBM) thickening were observed [53,57].

\subsubsection{Pharmacological Evaluation}

Anti-diabetic drugs that reduce insulin resistance or increase insulin sensitivity have been developed using KK $\mathrm{A}^{\mathrm{y}}$ mice. The first in the class of the TZD group of drugs, ciglitazone, was discovered in an in vivo screening system using $\mathrm{KK}^{\mathrm{y}}$ mice [62]. Moreover, pioglitazone was selected by Ikeda et al. [63]. These compounds decreased hyperinsulinemia, hyperglycemia, and hyperlipidemia, accompanied by improvement of insulin resistance. TZDs are considered to exert insulin-sensitizing action by binding to PPAR $\gamma$ [64]. Treatment with vanadium complex showed an amelioration in diabetes, obesity, and hypertension in $\mathrm{KK} \mathrm{A}^{\mathrm{y}}$ mice [65].

\subsection{Tsumura Suzuki Obese Diabetics (TSOD) Mouse}

\subsubsection{Background and Characteristics}

By the selective breeding of obese male mice of ddy strain and using indices of heavy body weight and appearance of urinary glucose, Suzuki et al. established two inbred strains in 1992: one with obesity and urinary glucose (TSOD) and the other without them (Tsumura Suzuki non obese: TSNO) [66,67].

The male TSOD mice showed diabetic symptoms, such as hyperphagia, polydipsia, obesity, hyperglycemia, hyperlipidemia, and hypeinsulinemia. Pancreatic islets of the TSOD mice showed hypertrophy with the increase in the number of $\beta$ cells and complete or partial degranulation of $\beta$ cells [66]. Iizuka et al. reported diabetic complications in TSOD mice in 2005 [68]. In the kidney, histological changes, such as thickening of the basement membrane in glomeruli and increase of the mesangial area were observed after 18 months of age. The motor neuropathy showed after 14 months of age, and the mice at 17 months of age showed weakness of front and hind 
paws caused by neuron degeneration. Moreover, in sensory neuropathy, the threshold in tail pressure test decreased at 12 months of age. In histopathological analysis at sciatic nerves at 18 and 22 months of age, TSOD mice showed a decrease in the density of nerve fibers by endoneural fibrosis and loss of these fibers. Furthermore, degenerative changes of myelinated fibers, separation of myelin sheaths with intralamellar edema and remyelination were observed. Kondo et al.

\section{CONCLUSION}

In this review, we overviewed the characteristic features of type 1 and type 2 diabetic mouse models and pharmacological evaluations using diabetic models. Various diabetic mouse models have been developed, and the models have played a key role in elucidating the pathogenesis of human diabetes and its complications. Moreover, diabetic mouse models are essential for developing novel drugs for diabetes and its complications. The importance of the mouse models will be a constant in the future, and establishment of novel mouse models is also necessary for further understanding of diabetic etiology and development of new therapies.

\section{REFERENCES}

[1] Wild, S., Roglic, G., Green, A., Sicree, R. and King, H. (2004) Global prevalence of diabetes: Estimates for the year 2000 and projections for 2030. Diabetes Care, 27, 1047-1053. http://dx.doi.org/10.2337/diacare.27.5.1047

[2] Inzucchi, S.E. and Sherwin, R.S. (2005) The prevention of type 2 diabetes mellitus. Endocrinology Metabolism Clinics of North America, 34, 199-219. http://dx.doi.org/10.1016/j.ecl.2004.11.008

[3] Kemmochi, Y., Fukui, K., Maki, M., Kimura, S., Ishii, Y., Sasase, T., Miyajima, K. and Ohta, T. (2013) Metabolic disorders and diabetic complications in Spontaneously Diabetic Torii Lepr $^{f a}$ (SDT fatty) Rat, a new obese type 2 diabetic model. Journal of Diabetes Research, Article ID: 948257, 9 pages.

[4] Makino, S., Kunimoto, K., Muraoka, Y., Mizushima, Y., Katagiri, K. and Tochino, Y. (1980) Breeding of nonobese diabetic strain of mice. Experimental Animals, 29, 1-13.

[5] Ohtori, H., Yoshida, T. and Inuma, T. (1968) Small eye and cataract, a new dominant mutation in the mouse. Experimental Animals, 17, 91-96.

[6] Makino, S., Muraoka, Y., Kishimoto, Y. and Hayashi, Y. (1985) Genetic analysis for insulitis in NOD mice. Experimental Animals, 34, 425-432.

[7] Elliott, R.B., Reddy, S.N., Bibby, N.J. and Kida, K. (1988) Dietary prevention of diabetes in the nonobese diabetic mouse. Diabetologia, 31, 62-64.

[8] Williams, A.J., Krug, J., Lampeter, E.F., Mansfield, K., Beales, P.E., Signore, A., Gale, E.A. and Pozzilli, P. (1990) Raised temperature reduces the incidence of diabetes in the NOD mouse. Diabetologia, 33, 635-637. http://dx.doi.org/10.1007/BF00400211

[9] Ohsugi, T. and Kurosawa, T. (1994) Increased incidence of diabetes mellitus in specific pathogen-eliminated offspring produced by embryo transfer in NOD mice with low incidence of the disease. Laboratory Animal Science, 44, 386-388.

[10] Beales P.E. and Pozzilli, P. (2002) Thiazolidinediones for the prevention of diabetes in the non-obese diabetic (NOD) mouse: Implications for human type 1 diabetes. Diabetes/Metabolism Research and Reviews, 18, 114-117. http://dx.doi.org/10.1002/dmrr.262

[11] Beales, P.E., Liddi, R., Giorgini, A.E., Signore, A., Procaccini, E., Batchelor, K. and Pozzilli, P. (1998) Troglitazone prevents insulin dependent diabetes in the non-obese diabetic mouse. European Journal of Pharmacology, 357, 221-225. http://dx.doi.org/10.1016/S0014-2999(98)00574-3

[12] Yang, Z., Chen, M., Carter, J.D., Nunemaker, C.S., Garmey, J.C., Kimble, S.D. and Nadler, J.L. (2006) Combined treatment with lisofylline and exendin-4 reverses autoimmune diabetes. Biochemical and Biophysical Research Communications, 344, 1017-1022. http://dx.doi.org/10.1016/j.bbrc.2006.03.177

[13] Johnson, C.G., Mikulowska, A., Butcher, E.C., McEvoy, L.M. and Michie, S.A. (1999) Anti-CD43 monoclonal antibody L11 blocks migration of T cells to inflamed pancreatic islets and prevents development of diabetes in nonobese diabetic mice. The Journal of Immunology, 163, 5678-5685.

[14] Yokono, K., Amano, K., Suenaga, K., Hari, J., Shii, K., Yaso, S., Yonezawa, K., Imamura, Y. and Baba, S. (19851986) Effect of antiserum to monoclonal anti-islet cell surface antibody on pancreatic insulitis in non-obese diabetic mice. Diabetes Research and Clinical Practice, 1, 315-321.

http://dx.doi.org/10.1016/S0168-8227(86)80043-2

[15] Yoshioka, M., Kayo, T., Ikeda, T. and Koizumi, A. (1997) A novel locus, Mody4, distal to D7Mit189 on chromosome 7 determines early-onset NIDDM in nonobese C57BL/6 (Akita) mutant mice. Diabetes, 46, 887-894. http://dx.doi.org/10.2337/diab.46.5.887

[16] Gurley, S.B., Mach, C.L., Stegbauer, J., Yang, J., Snow, K.P., Hu, A., Meyer, T.W. and Coffman, T.M. (2010) Influence of genetic background on albuminuria and kidney injury in Ins $2^{+/ C 96 Y}$ (Akita) mice. American Journal of Physiology-Renal Physiology, 298, F788-F795. http://dx.doi.org/10.1152/ajprenal.90515.2008

[17] Chang J.H. and Gurley, S.B. (2012) Assessment of diabetic nephropathy in the Akita mice. Methods in Molecular Biology, 933, 17-29.

[18] Ueno, Y., Horio, F., Uchida, K., Naito, M., Nomura, H., Kato, Y., Tsuda, T., Toyokuni, S. and Osawa, T. (2002) Increase in oxidative stress in kidneys of diabetic Akita mice. Bioscience, Biotechnology, and Biochemistry, 66, 869-872. http://dx.doi.org/10.1271/bbb.66.869

[19] de Preux Charles, A.S., Verdier, V., Zenker, J., Peter, B., Médard, J.J., Kuntzer, T., Beckmann, J.S., Bergmann, S. and Chrast, R. (2010) Global transcriptional programs in 
peripheral nerve endoneurium and DRG are resistant to the onset of type 1 diabetic neuropathy in Ins2 mice. PLoS One, 5, e10832. http://dx.doi.org/10.1371/journal.pone.0010832

[20] Wright, W.S., Yadav, A.S., McElhatten, R.M. and Harris, N.R. (2012) Retinal blood flow abnormalities following six months of hyperglycemia in the Ins2 (Akita) mouse. Experimental Eye Research, 98, 9-15. http://dx.doi.org/10.1016/j.exer.2012.03.003

[21] Gastinger, M.J., Kunselman, A.R., Conboy, E.E., Bronson, S.K. and Barber, A.J. (2008) Dendrite remodeling and other abnormalities in the retinal ganglion cells of Ins2 Akita diabetic mice. Investigative Opthalmology \& Visual Science, 49, 2635-2642. http://dx.doi.org/10.1167/iovs.07-0683

[22] Barber, A.J., Antonetti, D.A., Kern, T.S., Reiter, C.E., Soans, R.S., Krady, J.K., Levision, S.W., Gardner, T.W. and Bronson, S.K. (2005) The Ins2Akita mouse as a model of early retinal complications in diabetes. Investigative Opthalmology \& Visual Science, 46, 2210-2218. http://dx.doi.org/10.1167/iovs.04-1340

[23] Han, Z., Guo, J., Conley, S.M. and Naash, M.I. (2013) Retinal angiogenesis in the Ins2 (Akita) mouse model of diabetic retinopathy. Investigative Opthalmology \& Visual Science, 54, 574-584.

http://dx.doi.org/10.1167/iovs.12-10959

[24] Koshizaka, M., Takemoto, M., Sato, S., Tokuyama, H., Fujimoto, M., Okabe, E., Ishibashi, R., Ishikawa, T., Tsurutani, Y., Onishi, S., Mezawa, M., He, P., Honjo, S., Ueda, S., Saito, Y. and Yokote, K. (2012) An angiotensin II type 1 receptor blocker prevents renal injury via inhibition of the Notch pathway in Ins2 Akita diabetic mice. Experimental Diabetes Research, 2012, 159874. http://dx.doi.org/10.1155/2012/159874

[25] Chen, Y., Hu, Y., Lin, M., Jenkins, A.J., Keech, A.C., Mott, R., Lyons, T.J. and Ma, J.X. (2013) Therapeutic effects of PPAR $\alpha$ agonists on diabetic retinopathy in type 1 diabetes models. Diabetes, 62, 261-272. http://dx.doi.org/10.2337/db11-0413

[26] Ingalls, A.M., Dickie, M.M. and Snell, G.D. (1950) Obese, a new mutation in the house mouse. Journal of Heredity, 41, 317-318.

[27] Drasher, M.L., Dickie, M.M. and Lane, W.D. (1955) Physiological differences in uteri of obese stock mice. A comparison between obese mice and their thin sibs. Journal of Heredity, 46, 209-212.

[28] Contaldo, F., Gerber, H., Coward, W.A. and Trayhurn, P. (1981) Milk intake in pre-weanling genetically obese (ob/ ob) mice. In: Enzi, G., Crepaldi, G., Pozza, G. and Renold, A.E., Eds., Obesity: Pathogenesis and Treatment, Academic Press, London/New York, 319-322.

[29] Memon, R.A., Grunfeld, C., Moser, A.H. and Feingold, K.R. (1194) Fatty acid synthesis in obese insulin resistant diabetic mice. Hormone and Metabolic Research, 26, 8587. http://dx.doi.org/10.1055/s-2007-1000778

[30] Begin-Heick, N. (1996) Beta-adrenergic receptors and Gprotein in the ob/ob mouse. International Journal of Obesity, 20, S32-S35.

[31] Takeshita, S., Kawamura, I., Yasuno, T., Kimura, C., Ya- mamoto, T., Seki, J., Tamura, A., Sakurai, H. and Goto, T. (2001) Amelioration of insulin resistance in diabetic ob/ob mice by a new type of orally avtive insulin-mimetic vanadyl complex: Bis(1-oxy-2-piridinethiolato)oxovanadium(IV) with $\mathrm{VO}(\mathrm{S}(2) \mathrm{O}(2))$ coordination mode. Journal of Inorganic Biochemistry, 85, 179-186. http://dx.doi.org/10.1016/S0162-0134(01)00192-1

[32] Mackay, P., Ynddal, L., Andersen, J.V. and McCormack, J.G. (2003) Pharmacokinetics and anti-hyperglycaemic efficacy of a novel inhibitor of glycogen phosphorylase, 1,4-dideoxy-1,4-imino-d-arabinitol, in glucagon-challenged rats and dogs and in diabetic ob/ob mice. Diabetes, Obesity, and Metabolism, 5, 397-407. http://dx.doi.org/10.1046/j.1463-1326.2003.00293.x

[33] Schaeffer, P., Bernat, A., Arnone, M., Manara, L., Gallas, J.F., Dol-Gleizes, F., Millet, L., Grosset, A. and Herbert, J.M. (2206) Effect of SR58611A, a potent beta-3 adrenoceptor agonist, on cutaneous wound healing in diabetic and obese mice. European Journal of Pharmacology, 529, 172-178. http://dx.doi.org/10.1016/j.ejphar.2005.11.005

[34] Irwin, N., McClean, P.L., Cassidy, R.S., O'harte, F.P., Green, B.D., Gault, V.A., Harriott, P. and Flatt, P.R. (2007) Comparison of the anti-diabetic effects of GIP- and GLP1-receptor activation in obese diabetic (ob/ob) mice: Studies with DPP IV resistant N-AcGIP and exendin(139)amide. Diabetes/Metabolism Research and Reviews, 23, 572-579. http://dx.doi.org/10.1002/dmrr.729

[35] Fukuda, S., Ohta, T., Sakata, S., Morinaga, H., Ito, M., Nakagawa, Y., Tanaka, M. and Matsushita, M. (2010) Pharmacological profiles of a novel protein tyrosine phosphatase1B inhibitor, JTT-551. Diabetes, Obesity, and Metabolism, 12, 299-306. http://dx.doi.org/10.1111/j.1463-1326.2009.01162.x

[36] Hummel, K.P., Dickie, M.M. and Coleman, D.L. (1966) Diabetes, a new mutation in the mouse. Science, 153, 1127-1128. http://dx.doi.org/10.1126/science.153.3740.1127

[37] Allen, T.J., Cooper, M.E. and Lan, H.Y. (2004) Use of genetic mouse models in the study of diabetic nephropathy. Current Diabetes Reports, 4, 435-440. http://dx.doi.org/10.1007/s11892-004-0053-1

[38] Sharma, K., McCue, P. and Dunn, S.R. (2003) Diabetic kidney disease in the $\mathrm{db} / \mathrm{db}$ mice. American Journal of Physiology-Renal Physiology, 284, F1138-F1144.

[39] Islam, M.S. (2013) Animal models of diabetic neuropathy: Progress since 1960s. Journal of Diabetes Research, 2013, Article ID: 149452. http://dx.doi.org/10.1155/2013/149452

[40] Midena E., Segato, T., Radin, S., di Giorgio, G., Meneghini, F., Piermarocchi, S. and Belloni, A.S. (1989) Studies on the retina of the diabetic $\mathrm{db} / \mathrm{db}$ mouse. I. Endothelial cell-pericyte ratio. Ophthalmic Research, 21, 106-111. http://dx.doi.org/10.1159/000266787

[41] Robertson, D.M. and Sima, A.A. (1980) Diabetic neuronpathy in the mutant mouse [C57BL/ks(db/db)]: A morphometric study. Diabetes, 29, 60-67. http://dx.doi.org/10.2337/diab.29.1.60

[42] Sima, A.A. and Robertson, D.M. (1978) Peripheral neuropathy in mutant diabetic mouse [C57BL/ks $(\mathrm{db} / \mathrm{db})]$. Acta 
Neuropathologica, 41, 85-89.

http://dx.doi.org/10.1007/BF00689757

[43] Oshima, H., Yoshida, S., Ohishi, T., Matsui, T., Tanaka, H., Yonetoku, Y., Shibasaki, M. and Uchiyama, Y. (2013) Novel GPR119 agonist AS1669058 potentiates insulin secretion from rat islets and has potent anti-diabetic effects in ICR and diabetic $\mathrm{db} / \mathrm{db}$ mice. Life Science, 92, 167173. http://dx.doi.org/10.1016/j.lfs.2012.11.015

[44] Wang, C.D., Teng, B.S., He, Y.M., Wu, J.S., Pan, D., Pan, L.F., Zhang, D., Fan, Z.H., Yang, H.J. and Zhou, P. (2012) Effect of a novel proteoglycan PTP1B inhibitor from $\mathrm{Ga}$ noderma lucidum on the amelioration of hyperglycaemia and dyslipidaemia in $\mathrm{db} / \mathrm{db}$ mice. British Journal of $\mathrm{Nu}$ trition, 108, 2014-2025.

http://dx.doi.org/10.1017/S0007114512000153

[45] Kawashima, S., Matsuoka, T.A., Kaneto, H., Tochino, Y., Kato, K., Yamamoto, K., Yamamoto, T., Matsuhisa, M. and Shimomura, I. (2011) Effect of alogliptin, pioglitazone and glargine on pancreatic $\beta$-cells in diabetic $\mathrm{db} / \mathrm{db}$ mice. Biochemical and Biophysical Research Communications, 404, 534-540.

http://dx.doi.org/10.1016/j.bbrc.2010.12.021

[46] Kim, H.W., Lee, J.E., Cha, J.J., Hyun, Y.Y., Kim, J.E., Lee, M.H., Song, H.K., Nam, D.H., Han, J.Y., Han, S.Y., Han, K.H., Kang, Y.S. and Cha, D.R. (2013) Fibroblast growth factor 21 improves insulin resistance and ameliorates renal injury in db/db mice. Endocrinology, 154, 33663376. http://dx.doi.org/10.1210/en.2012-2276

[47] Loeffler, I., Ruester, C., Franks, S., Liebisch, M. and Wolf, G. (2013) Erythropoietin ameliorates podocyte injury in advanced diabetic nephropathy in the $\mathrm{db} / \mathrm{db}$ mice. American Journal of Physiology-Renal Physiology. http://dx.doi.org/10.1152/ajprenal.00643.2012

[48] Seok, S.J., Lee, E.S., Kim, G.T., Hyun, M., Lee, J.H., Chen, S., Choi, R., Kim, H.M., Lee, E.Y. and Chung, C.H. (2013) Blockade of CCL2/CCR2 signaling ameliorates diabetic nephropathy in $\mathrm{db} / \mathrm{db}$ mice. Nephrology Dialysis Transplantation, 28, 1700-1710. http://dx.doi.org/10.1093/ndt/gfs555

[49] Zhang, L., Li, R., Shi, W., Liang, X., Liu, S., Ye, Z., Yu, C., Chen, Y., Zhang, B., Wang, W., Lai, Y., Ma, J., Li, Z. and Tan, X. (2013) NFAT2 inhibitor ameliorates diabetic nephropathy and podocyte injury in $\mathrm{db} / \mathrm{db}$ mice. British Journal of Pharmacology, 170, 426-439.

[50] Nagata, T., Fukuzawa, T., Takeda, M., Fukazawa, M., Mori, T., Nihei, T., Honda, K., Suzuki, Y. and Kawabe, Y. (2013) Tofogliflozin, a novel sodium-glucose co-transporter 2 inhibitor, improves renal and pancreatic function in $\mathrm{db} / \mathrm{db}$ mice. British Journal of Pharmacology, 170, 519531. http://dx.doi.org/10.1111/bph.12269

[51] Kim, J.E., Lee, M.H., Nam, D.H., Song, H.K., Kang, Y.S., Lee, J.E., Kim, H.W., Cha, J.J., Hyun, Y.Y., Han, S.Y., Han, K.H., Han, J.Y. and Cha, D.R. (2013) Celastrol, an $\mathrm{NF}-\kappa \mathrm{B}$ inhibitor, improves insulin resistance and attenuates renal injury in $\mathrm{db} / \mathrm{db}$ mice. PLoS One, 8, Article ID: E62068. http://dx.doi.org/10.1371/journal.pone.0062068

[52] Kondo, K., Nozawa, K., Tomita,T. and Ezaki, K. (1957) Inbred strains resulting from Japanese mice. Bull Experimental Animals, 6, 107-112.
[53] Nakamura, M. (1962) A diabetic strain of the mouse. Proceedings of the Japan Academy, 38, 348-352.

[54] Nishimura, M. (1969) Breeding of mice strains for diabetes mellitus. Experimental Animals, 18, 147-157.

[55] Bultman, S., Michaud, E.J. and Woychik, R.P. (1992) Molecular characterization of the mouse agouti locus. Cell, 71, 1195-1204. http://dx.doi.org/10.1016/S0092-8674(05)80067-4

[56] Michaud, E.J., Bultman, S.J., Klebig, M.L., van Vugt, M.J., Stubbs, L.J., Russell, L.B. and Woychik, R.P. (1994) A molecular model for the genetic and phenotypic characteristics of the mouse lethal yellow (Ay) mutation. Proceedings of the National Academy of Science, 91, 25622566. http://dx.doi.org/10.1073/pnas.91.7.2562

[57] Iwatsuka, H. and Shino, A. (1970) Studies on diabetogenic action of obesity in mice: Congenital insulin resistance of KK mice. Endocrine Journal, 17, 535-540. http://dx.doi.org/10.1507/endocrj1954.17.535

[58] Iwatsuka, H., Taketomi, S., Matsuo, T. and Suzuoki, Z. (1974) Congenitally impaired hormone sensitivity of the adipose tissue of spontaneously diabetic mice, KK. Validity of thrifty genotype in KK mice. Diabetologia, 10, 611616. http://dx.doi.org/10.1007/BF01221994

[59] Taketomi, S., Tsuda, M., Matsuo, T., Iwatsuka, H. and Suzuoki, Z. (1973) Alternations of hepatic enzyme activeties in $\mathrm{KK}$ and yellow $\mathrm{KK}$ mice with various diabetic states. Hormone and Metabolic Research, 5, 333-339. http://dx.doi.org/10.1055/s-0028-1093938

[60] Hofman, C., Lorenz, K. and Colca, J.R. (1991) Glucose transport deficiency in diabetic animals is corrected by treatment with oral antihyperglycemic agent pioglitazone. Endocrinology, 129, 1915-1925.

http://dx.doi.org/10.1210/endo-129-4-1915

[61] Iwatsuka, H., Shino, A. and Suzuoki, Z. (1970) General survey of diabetic features of yellow KK mice. Endocrine Journal, 17, 23-35. http://dx.doi.org/10.1507/endocrj1954.17.23

[62] Fujita, T., Sugiyama, Y., Taketomi, S., Sohda, T., Kawamatsu, Y., Iwatsuka, H. and Suzuoki, Z. (1983) Reduction of insulin resistance in obese and/or diabetic animals by 5-\{4-(1-methylcyclohexylmethoxy)benzyl $\}$-thiazolidine-2,4dione (ADD-3878, U-63,287, ciglitazone) a new antidiabetic agent. Diabetes, 32, 804-810. http://dx.doi.org/10.2337/diab.32.9.804

[63] Ikeda, H., Taketomi, S., Sugiyama, Y., Shimura, Y., Sohda, T., Meguro, K. and Fujita, T. (1990) Effects on pioglitazone on glucose and lipid metabolism in normal and insulin resistant animals. Arzneimittelforschung, 40, 156-162.

[64] Willson, T.M., Cobb, J.E., Cowan, D.J. Wiethe, R.W., Correa, I.D., Prakash, S.R., Beck, K.D., Moore, L.B., Kliewer, S.A. and Lehmann, J.M. (1996) The structure-activity relationship between peroxisome proliferator-activated receptor gamma agonism and the antihyperglycemic avtivity of thiazolidinediones. Journal of Medicinal Chemistry, 39, 665-668. http://dx.doi.org/10.1021/jm950395a

[65] Adachi, Y., Yoshikawa, Y., Kodera, Y., Katoh, A., Takeda, J. and Sakurai, H. (2006) Improvement in diabetes, obesity and hypertension in type 2 diabetic KKA(y) mice by 
bis(allixunato)oxovanadium(IV) complex. Biochemical and Biophysical Research Communications, 345, 945-950. http://dx.doi.org/10.1016/j.bbrc.2006.05.003

[66] Suzuki, W., Iizuka, S., Tabuchi, M., Funo, S., Yanagisawa, T., Kimura, M., Sato, T., Endo, T. and Kawamura, H. (1999) A new mouse model of spontaneous diabetes derived from ddY strain. Experimental Animals, 48, 181-189. http://dx.doi.org/10.1538/expanim.48.181

[67] Hirayama, I., Yi, Z., Izumi, S., Arai, I., Suzuki, W., Nagamachi, Y., Kuwano, H., Takeuchi, T. and Izumi, T. (1999)
Genetic analysis of obese diabetes in the TSOD mouse. Diabetes, 48, 1183-1191.

http://dx.doi.org/10.2337/diabetes.48.5.1183

[68] Iizuka, S., Suzuki,W., Tabuchi, M., Nagata, M., Imamura, S., Kobayashi, Y., Kanitani, M., Yanagisawa, T., Kase, Y., Takeda, S., Aburada, M. and Takahashi, K.W. (2005) Diabetic complications in a new animal model (TSOD mouse) of spontaneous NIDDM with obesity. Experimental Animals, 54, 71-83.

http://dx.doi.org/10.1538/expanim.54.71 